\title{
The effect of empowerment education on depression level and laboratory indicators of patients treated with hemodialysis: a meta-analysis
}

Original article

Yu-Nan Ji, Yan-Hui Liu*, Ling-Li Xie, Chen-Yang Li, Zhen-Hua Hou

School of Nursing, Tianjin University of Traditional Chinese Medicine, Tianjin 300193, China

Received: 28 September 2018; Accepted: 29 December 2018; Published: 20 September 2019

Abstract: Objective: The objective of this study was to evaluate the effect of empowerment education on depression level and laboratory indicators of patients treated with hemodialysis.

Methods: We searched databases including Cochrane Library, Web of Science, Embase, PubMed, Chinese Biomedical Literature Database (CBM), Chinese Academic Journals Full-text Database (CNKI), VIP, and Wanfang. We included all the researches about the application of empowerment education in patients treated with hemodialysis. We used RevMan 5.3 to analyze the data after assessing the quality of researches.

Results: We included 10 studies eventually. The results of meta-analysis showed that the self-efficacy [MD $=1.10,95 \%$ confidence interval (Cl; 0.71, 1.48), $P<0.01]$, depression [MD $=-6.94,95 \% \mathrm{Cl}(-8.53,-5.34), P<0.01]$, serum creatinine [Scr; $\mathrm{MD}=-116.46$, $95 \% \mathrm{Cl}(-171.90,-61.03), P<0.01]$, albumin [Alb; $\mathrm{MD}=2.93,95 \% \mathrm{Cl}(2.00,3.86), P<0.01]$, and blood urea nitrogen [BUN; $\mathrm{MD}=-0.95,95 \% \mathrm{Cl}(-1.89,-0.01), P=0.05]$ in the empowerment education group had significantly statistical difference compared with those in the usual education group. However, there was no significant difference in hemoglobin $[\mathrm{Hb} ; \mathrm{MD}=3.03,95 \% \mathrm{Cl}(-0.64$, $6.70), P=0.11]$ between two groups.

Conclusions: Empowerment education can improve the self-efficacy in patients treated with hemodialysis, relieve depression, and improve Scr, Alb, and BUN. However, there is no significant improvement in $\mathrm{Hb}$; it needs further exploration in clinical practice.

Keywords: empowerment education • hemodialysis $(H D) \cdot$ depression • laboratory indicators • meta-analysis

(c) Shanxi Medical Periodical Press.

\section{Introduction}

At present, with the increase in the incidence of endstage renal disease, the number of hemodialysis patients in China is increasing, even is higher than the growth rate of the world. ${ }^{1}$ As a long-term traumatic replacement therapy, hemodialysis not only reduces the patient's related symptoms and prolongs the survival period but also causes a variety of physiological and psychological problems in the patient, which seriously affects his or her quality of life..$^{2,3} \mathrm{~A}$ study ${ }^{4}$ has shown that depression is a common emotional disorder in maintenance hemodialysis patients, with an incidence of $30 \%-100 \%$. As a new model of health education, empowerment education has changed the passive obedience of the patients in the traditional education and makes the passive patients to be active, and it also can manage the self-management. ${ }^{5}$ In recent years, empowerment education has shown a

How to cite this article: Ji YN, Liu YH, Xie LL, Li CY, Hou ZH. The effect of empowerment education on depression level and laboratory indicators of patients treated with hemodialysis: a meta-analysis. Front Nurs. 2019; 3: $217-226$. 
good effect on improving biochemical indicators such as glycosylated hemoglobin $(\mathrm{Hb}) .{ }^{6}$ Research on the application of empowerment education in hemodialysis patients has also been deepened and has attracted more and more attention. The study of $\mathrm{McCarley}^{7}$ shows that empowerment can stimulate self-care and self-management in hemodialysis patients. A qualitative study of the empowerment education in 27 hemodialysis patients by Christian et al. ${ }^{8}$ found that the patient's satisfaction with the empowerment process is $100 \%$, and half of the respondents said that they were willing to participate in the empowerment education.

However, there are still differences in the role of $\mathrm{Hb}$ and other biochemical indicators in hemodialysis patients, and most of the studies have the problems of relatively small sample size and scattered cases. Therefore, the purpose of this study was to evaluate the effect of empowerment education on self-efficacy, depression, blood creatinine, $\mathrm{Hb}$, albumin (Alb), and other biochemical indicators of hemodialysis patients by meta-analysis. These can provide a reference for further clinical study of the empowerment education intervention for hemodialysis patients.

\section{Design and methods}

\subsection{Inclusion and exclusion criteria}

\subsubsection{Study type}

Randomized controlled trials (RCTs) or class experiments in both Chinese and English were eligible for inclusion in this meta-analysis.

\subsubsection{Study objective}

The inclusion criteria were as follows: (1) Conduct regular hemodialysis for at least 3 months; (2) have communication abilities and be able to understand and cooperate with; (3) volunteers to participate in the study; and (4) age $\geq 18$ years. People with mental illness and mental handicap were excluded.

\subsubsection{Study intervention}

Empowerment education was provided to hemodialysis patients in the experimental group. Empowerment education contained contents such as related knowledge about hemodialysis; diet management, such as the importance and principles of diet, exercise; appropriate use of medicines; and management of negative emotions. The traditional education was adopted in the control group.

\subsubsection{Outcome measures}

The outcome measures were self-efficacy [the Chronic Disease Management Self-Efficacy Scale and Strategies Used by People to Promote Health (SUPPH)], depression [Self-Rating Depression Scale (SDS)], and blood biochemical indicators $[\mathrm{Hb}$, Alb, serum creatinine (Scr), blood urea nitrogen (BUN), empowerment level, and Empowerment Scale (ES)].

\subsection{Search strategy}

We used computer to search some databases such as Cochrane Library, Web of Science, PubMed, Chinese Biomedical Literature Database (CBM), Chinese Academic Journals Full-text Database (CNKI), VIP Database (VIP) and Wanfang Data Knowledge Service Platform. The retrieval time was from the establishment of the database to November, 2017. English search terms were empower*, empowerment theory, empowerment education, renal dialysis, renal dialyses, hemodialysis, hemodialyses, haemodialysis, haemodialyses, extracorporeal dialyses, extracorporeal dialysis, and hemodiafiltrat*; Chinese search terms were empowerment theory, empowerment education; hemodialysis hemodialysis, hemodiafiltration, hemofiltration, plasma exchange, and blood perfusion. MeSH subject terms, free words, and Boolean operators were used to combine word combinations; corresponding search-based search literatures were formulated based on different databases; and references included in original documents and related reviews were referred to determine other relevant literature.

\subsection{Data extraction}

Two researchers independently selected the literature according to the inclusion and exclusion criteria, crosschecked after extracting the literature data, and if there were any objections, they were resolved through arbitration by the third researcher. According to the content of the literature, a data extraction form was prepared. The extracted contents included the included literature, publication time, sample size, interventions, intervention time, and data extraction time and outcome indicators.

\subsection{Risk of bias assessment}

Two investigators evaluated the quality of the included literature according to the Cochrane Handbook Quality Standards 2011. The evaluation items included random sequence generation, allocation concealment, blinding of study subjects and implementers, blinding of outcome measurers, completeness of result data, selective 
reporting of study results, and other sources of bias. According to the above criteria, each article included was evaluated one by one using "low risk of bias", "high risk of bias", or "unclear". Literature quality was divided into three levels: A, B, and C. The characteristics of "Grade $A$ " were low biased and fully satisfying the above quality standards, "Grade B" were moderately biased and partially satisfying the above quality standards, and "Grade C" were highly biased and completely dissatisfied with the abovementioned quality standards; such documents were excluded. After independently evaluating the quality of the literature, two researchers discussed the quality of each study based on the above evaluation criteria and reached a consensus to form the final evaluation of the quality of the literature. If there were differences, the third researcher arbitrated.

\subsection{Statistical analysis}

RevMan 5.3 software was used for meta-analysis. Measured data were expressed as the weighted mean difference (MD) or standardized mean difference (SMD) and its $95 \%$ confidence interval $(\mathrm{Cl})$. Count data used relative risk $(\mathrm{RR})$ or odds ratio $(\mathrm{OR})$ and $95 \% \mathrm{Cl}$. The heterogeneity between the results of the included studies was determined using the $Q$ test, and the effectivity values were analyzed for heterogeneity. If there was no statistically significant heterogeneity between studies $(P>0.1$, $P^{2}<50 \%$ ), a fixed-effects model was used. If there was statistical heterogeneity $\left(P<0.1, P^{2} \geq 50 \%\right)$, these factors, which may lead to heterogeneity, were analyzed in subgroups. If there was a statistical difference and no clinical heterogeneity between the two groups, or difference was not statistically significant, a random effects

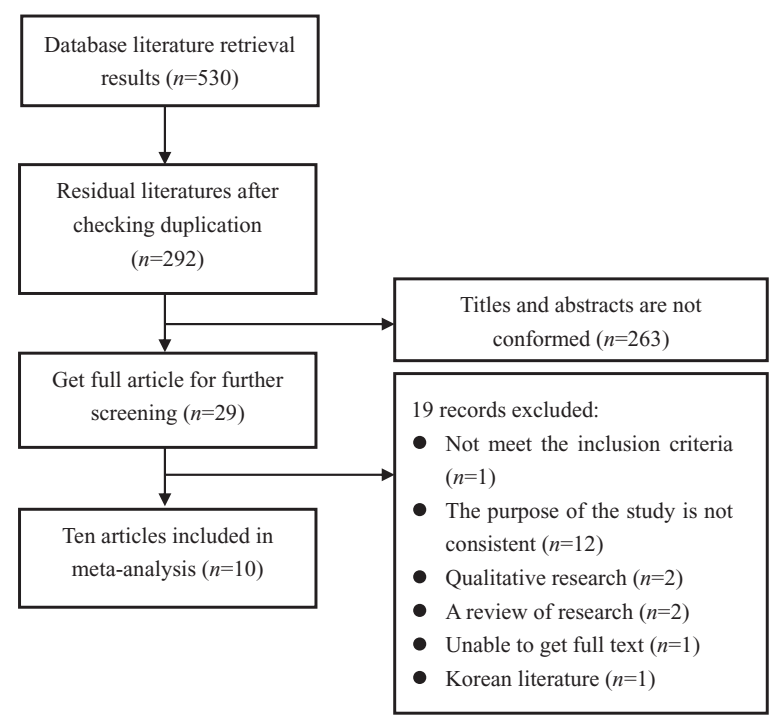

Figure 1. Flow chart of the study selection procedure. model was used to combine the effect sizes. If the heterogeneity was too obvious and the source could not be judged, a descriptive analysis was performed.

\section{Results}

\subsection{Study selection}

A total of 530 reports in literature were retrieved, including 106 Chinese studies and 424 English studies. After removing duplicate literature with NoteExpress, there were 292 studies, including 41 in Chinese and 251 in English; after reading the title, abstract, and full text, the studies that did not meet the inclusion criteria were deleted, and finally, 10 studies were identified. See Figure 1 for details.

\subsection{Methodological quality}

For the 10 studies included, the total sample size was 817; the basic characteristics of the included studies are given in Table 1. The quality of the 10 studies included was evaluated by the Cochrane Systematic Review Manual 5.1.0. Some of the studies were lost to follow-up, but all were explained. Among the 10 studies included in the results, one had a quality rating of A and the others had a quality rating of B. See Table 2 for details.

\subsection{Primary outcomes}

\subsubsection{Effect of empowerment education intervention on self-efficacy}

Eight studies ${ }^{9,10,12-14,16-18}$ used the Chronic Disease Management Self-Efficacy Scale or Strategies Used by People to Promote Health (SUPPH) to measure the impact of empowerment education intervention on the self-efficacy of hemodialysis patients. Efficacy scales have good reliability and validity. The combined results showed that there was statistical heterogeneity among the studies $\left(P<0.1, P^{2}=81 \%\right)$, so the random effects model was used for meta-analysis. The results showed that the self-efficacy score of the empowerment education group was higher than that of the control group, and the difference was statistically significant $[M D=1.10$, $95 \% \mathrm{Cl}(0.71,1.48), P<0.01]$. That is, empowerment education intervention can improve the self-efficacy of hemodialysis patients. Taking into account the greater heterogeneity, the included studies were grouped into subgroup analyses by data collection time. The results showed that measured for 6 weeks in hemodialysis patients, empowerment education intervention can improve the self-efficacy of hemodialysis patients $[\mathrm{MD}=8.83,95 \% \mathrm{Cl}(5.49,12.17), P<0.01]$ and measured 


\begin{tabular}{|c|c|c|c|c|c|c|c|c|}
\hline \multirow[t]{2}{*}{ Study } & \multirow{2}{*}{$\begin{array}{c}\text { Publication } \\
\text { year }\end{array}$} & \multicolumn{2}{|c|}{ Samples } & \multicolumn{2}{|c|}{ Intervention } & \multirow[t]{2}{*}{ Intervention time } & \multirow{2}{*}{$\begin{array}{l}\text { Data extraction } \\
\text { time }\end{array}$} & \multirow[t]{2}{*}{ Outcomes } \\
\hline & & $\mathrm{E}$ & $\mathrm{C}$ & $\mathrm{E}$ & $\mathrm{C}$ & & & \\
\hline Zhang $^{9}$ & 2013 & 36 & 35 & $\begin{array}{l}\text { Empowerment } \\
\text { education }\end{array}$ & $\begin{array}{l}\text { General health } \\
\text { education }\end{array}$ & $\begin{array}{l}6 \text { weeks, once a } \\
\text { week, } 90 \text { minutes } \\
\text { each time; follow- } \\
\text { up } 6 \text { months, } \\
2 \text { times a month, } \\
\text { 10-15 minutes } \\
\text { each time }\end{array}$ & $\begin{array}{l}3 \text { months, } \\
6 \text { months }\end{array}$ & $\begin{array}{l}\text { Self-efficacy, } \\
\text { depression, } \\
\mathrm{Hb}, \mathrm{Alb}, \mathrm{Scr}\end{array}$ \\
\hline Zhao ${ }^{10}$ & 2015 & 63 & 63 & $\begin{array}{l}\text { Empowerment } \\
\text { education }\end{array}$ & $\begin{array}{l}\text { Health } \\
\text { education }\end{array}$ & $\begin{array}{l}2 \text { months, once } \\
\text { every } 2 \text { weeks, } \\
90 \text { minutes each } \\
\text { time; follow-up } \\
4 \text { months, once } \\
\text { every } 2 \text { weeks, } \\
\text { 10-15 minutes } \\
\text { each time }\end{array}$ & 6 months & Self-efficacy \\
\hline Du et al. ${ }^{11}$ & 2017 & 64 & 67 & $\begin{array}{l}\text { Empowerment } \\
\text { education diet } \\
\text { management }\end{array}$ & $\begin{array}{l}\text { Traditional } \\
\text { diet health } \\
\text { education }\end{array}$ & $\begin{array}{l}6 \text { months, once } \\
\text { a month; follow- } \\
\text { up one time after } \\
1-2 \text { weeks }\end{array}$ & $\begin{array}{l}3 \text { months, } \\
6 \text { months }\end{array}$ & Alb \\
\hline Gan et al. ${ }^{12}$ & 2015 & 40 & 40 & $\begin{array}{l}\text { Empowerment } \\
\text { education }+ \\
\text { general health } \\
\text { education }\end{array}$ & $\begin{array}{l}\text { General health } \\
\text { education }\end{array}$ & $\begin{array}{l}\text { (1) } 6 \text { months; } \\
\text { follow-up two } \\
\text { times a month, } \\
\text { 10-15 minutes } \\
\text { each time; } \\
\text { (2) } 6 \text { weeks, once a } \\
\text { week, } 90 \text { minutes } \\
\text { each time }\end{array}$ & $\begin{array}{l}3 \text { months, } \\
6 \text { months }\end{array}$ & $\begin{array}{l}\text { Self-efficacy, } \\
\text { depression }\end{array}$ \\
\hline Qiao $^{13}$ & 2014 & 47 & 40 & $\begin{array}{l}\text { Empowerment } \\
\text { education }\end{array}$ & $\begin{array}{l}\text { General health } \\
\text { education }\end{array}$ & $\begin{array}{l}12 \text { weeks, once } \\
\text { every } 2 \text { weeks, } \\
120 \text { minutes each } \\
\text { time }\end{array}$ & 3 months & Self-efficacy \\
\hline $\operatorname{Ran}^{14}$ & 2016 & 40 & 40 & $\begin{array}{l}\text { Empowerment } \\
\text { education }\end{array}$ & $\begin{array}{l}\text { General health } \\
\text { education }\end{array}$ & $\begin{array}{l}6 \text { weeks, two times } \\
\text { a week, } 45 \text { minutes } \\
\text { each time }\end{array}$ & $\begin{array}{l}3 \text { months, } \\
6 \text { months }\end{array}$ & $\begin{array}{l}\text { Self-efficacy, } \\
\text { depression, } \\
\text { Scr, Hb, Alb }\end{array}$ \\
\hline Bian et al. ${ }^{15}$ & 2017 & 31 & 31 & $\begin{array}{l}\text { Empowerment } \\
\text { education }\end{array}$ & $\begin{array}{l}\text { General } \\
\text { diet health } \\
\text { education }\end{array}$ & $\begin{array}{l}3 \text { months, once a } \\
\text { week, one time a } \\
\text { week, } 60 \text { minutes } \\
\text { each time; follow- } \\
\text { up } 6 \text { months, one } \\
\text { time a month, } \\
\text { 10-15 minutes } \\
\text { each time }\end{array}$ & $\begin{array}{l}1 \text { month, } \\
3 \text { months, } \\
6 \text { months }\end{array}$ & Alb, Hb, Scr, BUN \\
\hline $\begin{array}{l}\text { Moattari } \\
\text { et al. }{ }^{16}\end{array}$ & 2012 & 25 & 23 & $\begin{array}{l}\text { Empowerment } \\
\text { education }\end{array}$ & $\begin{array}{l}\text { General } \\
\text { treatment }\end{array}$ & $\begin{array}{l}6 \text { weeks, four } \\
\text { individual and two } \\
\text { group counseling } \\
\text { sessions, two } \\
\text { sessions for } \\
1.5-2 \text { hours }\end{array}$ & 6 weeks & $\begin{array}{l}\text { Self-efficacy, } \\
\mathrm{Hb}, \mathrm{BUN}\end{array}$ \\
\hline Royani et al. ${ }^{17}$ & 2013 & 40 & 40 & $\begin{array}{l}\text { Empowerment } \\
\text { education }\end{array}$ & $\begin{array}{l}\text { General health } \\
\text { education }\end{array}$ & $\begin{array}{l}1 \text { month, twice a } \\
\text { week }\end{array}$ & 1 month & $\begin{array}{l}\text { Empowerment, } \\
\text { Self-efficacy }\end{array}$ \\
\hline Tsay et al. ${ }^{18}$ & 2004 & 25 & 25 & $\begin{array}{l}\text { Empowerment } \\
\text { education }\end{array}$ & $\begin{array}{l}\text { Traditional } \\
\text { education }\end{array}$ & 4 weeks & $\begin{array}{l}6 \text { weeks } \\
\text { following the } \\
\text { intervention }\end{array}$ & $\begin{array}{l}\text { Empowerment, } \\
\text { depression }\end{array}$ \\
\hline
\end{tabular}

Note: E: empowerment education group; C: control group; Hb: hemoglobin; Alb: albumin; Scr: serum creatinine; BUN: blood urea nitrogen.

Table 1. Basic characteristics of the included studies.

for 3 months in hemodialysis patients, education intervention can improve self-efficacy $[\mathrm{MD}=0.62,95 \% \mathrm{Cl}$ (0.43, 0.81), $P<0.01$ ]; 6-month self-efficacy of hemodialysis patients can also be improved in empowerment education interventions $[\mathrm{MD}=1.39,95 \% \mathrm{Cl}(1.17,1.61)$, $P<0.01$ ] (see Figures 2-4).

\subsubsection{Effect of empowerment education intervention on depression level}

All three studies $^{9,12,14}$ used depression self-rating scales to measure the level of depression in hemodialysis patients. The combined results showed that there was no statistical heterogeneity between the studies 


\begin{tabular}{|c|c|c|c|c|c|c|c|c|}
\hline \multirow[t]{2}{*}{ Study } & \multirow{2}{*}{$\begin{array}{l}\text { Random } \\
\text { sequence } \\
\text { generation }\end{array}$} & \multirow{2}{*}{$\begin{array}{c}\text { Allocation } \\
\text { concealment }\end{array}$} & \multicolumn{2}{|c|}{ Blinding } & \multirow{2}{*}{$\begin{array}{c}\text { Incomplete } \\
\text { outcome data }\end{array}$} & \multirow{2}{*}{$\begin{array}{l}\text { Selective } \\
\text { reporting }\end{array}$} & \multirow{2}{*}{$\begin{array}{l}\text { Other } \\
\text { bias }\end{array}$} & \multirow[t]{2}{*}{ Grade } \\
\hline & & & $\begin{array}{c}\text { Participants and } \\
\text { personnel }\end{array}$ & $\begin{array}{c}\text { Outcome } \\
\text { assessment }\end{array}$ & & & & \\
\hline Zhang $^{9}$ & Low risk & Not clear & Not clear & Not clear & Low risk & Low risk & Not clear & $B$ \\
\hline Zhao ${ }^{10}$ & High risk & Not clear & Not clear & Not clear & Low risk & Not clear & Not clear & $B$ \\
\hline Du et al. ${ }^{11}$ & High risk & Not clear & Not clear & Not clear & Low risk & Not clear & Not clear & B \\
\hline Gan et al. ${ }^{12}$ & Low risk & Not clear & Not clear & Not clear & Low risk & Not clear & Not clear & B \\
\hline $\mathrm{Qiao}^{13}$ & Low risk & Not clear & Not clear & Not clear & Low risk & Low risk & Not clear & B \\
\hline $\operatorname{Ran}^{14}$ & Low risk & Not clear & Not clear & Not clear & Low risk & Not clear & Not clear & $\mathrm{B}$ \\
\hline Bian et al. ${ }^{15}$ & Low risk & Not clear & Not clear & Not clear & Low risk & Not clear & Not clear & B \\
\hline Moattari et al. ${ }^{16}$ & Low risk & Not clear & Not clear & Not clear & Low risk & Not clear & Not clear & B \\
\hline Royani et al. ${ }^{17}$ & Low risk & Not clear & Not clear & Not clear & Low risk & Not clear & Not clear & B \\
\hline Tsay et al. ${ }^{18}$ & Low risk & Not clear & Low risk & Low risk & Low risk & Low risk & Not clear & $A$ \\
\hline
\end{tabular}

Table 2. Methodological quality assessment of included studies.

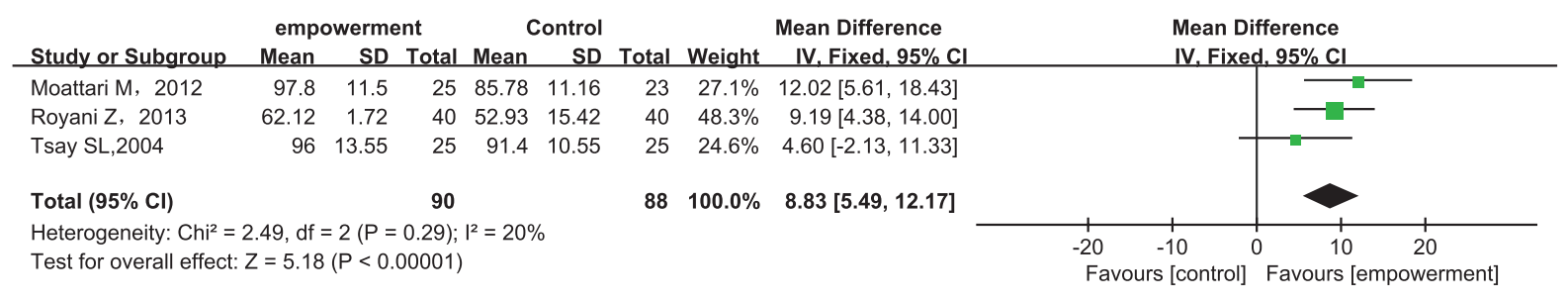

Figure 2. Comparison of 6-week self-efficacy between empowerment education intervention group and traditional education group.

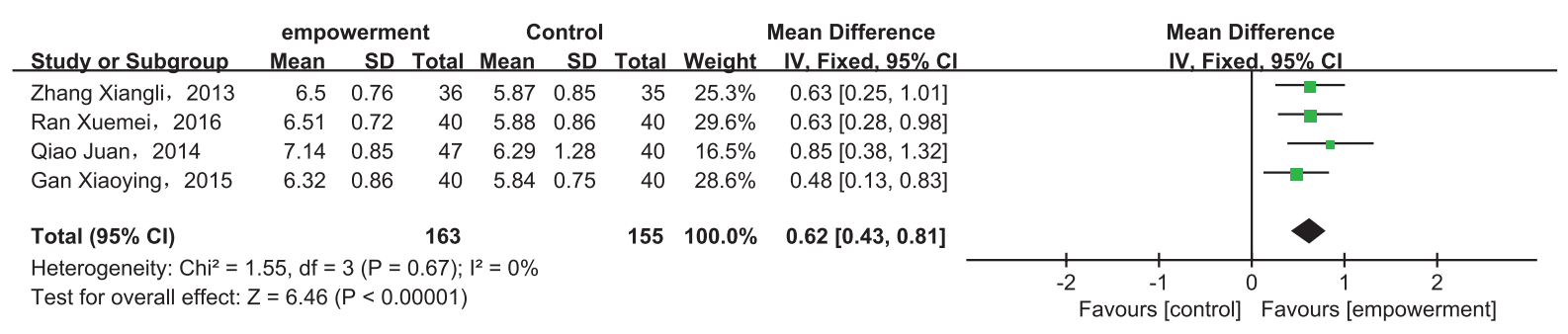

Figure 3. Comparison of 3-month self-efficacy between empowerment education intervention group and traditional education group.

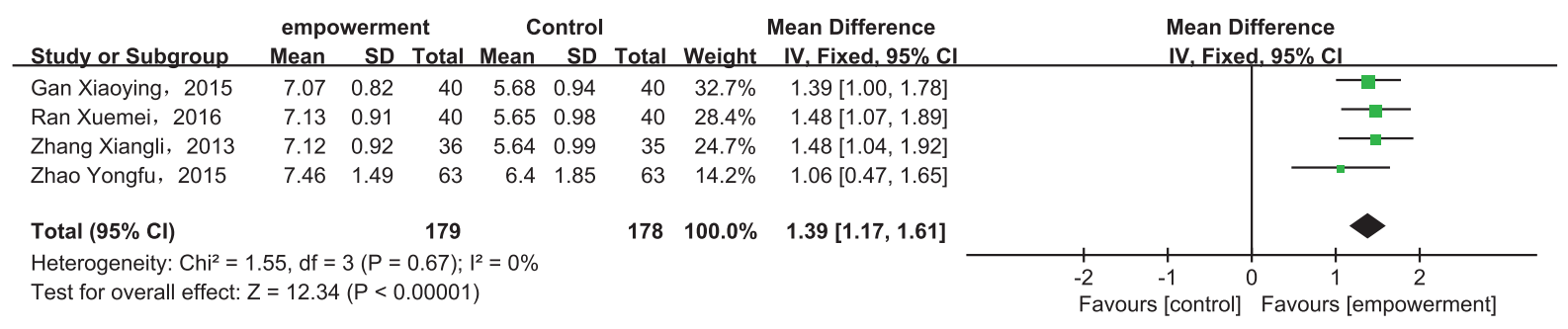

Figure 4. Comparison of 6-month self-efficacy between empowerment education intervention group and traditional education group.

$\left(P=0.17, P^{2}=35 \%\right)$, so a fixed-effect model was used for meta-analysis. The results showed that the level of depression in the empowerment education intervention group was lower than that in the control group and the difference was statistically significant $[\mathrm{MD}=-6.94,95 \%$ Cl (-8.53, -5.34), $P<0.01]$, namely, empowerment education can alleviate depression in hemodialysis patients. Because the intervention time was 3 months 
and 6 months, a subgroup analysis was conducted to investigate the effects of interventions at different times on the level of depression in hemodialysis patients. The results showed that 3 months and 6 months of empowerment education intervention could alleviate the depression of hemodialysis patients [3 months: $\mathrm{MD}=-4.62,95 \% \mathrm{Cl}(-6.90,-2.33), P<0.01 ; 6$ months: $\mathrm{MD}=-9.14,95 \% \mathrm{Cl}(-11.36,-6.91), P<0.01]$ (see Figure 5).

\subsubsection{Effect of empowerment education intervention on blood biochemical indexes}

\subsubsection{Effect of empowerment education intervention on $\mathrm{Hb}$}

Four studies ${ }^{9,14-16}$ compared the effects of empowerment education intervention on $\mathrm{Hb}$ in hemodialysis patients. The combined results showed that there was statistical heterogeneity among the studies $(P=0.02$, $P^{2}=60 \%$ ), so a random effect model was used for meta-analysis. The results showed that there was no statistically significant difference between the empowerment education intervention group and the control group $[\mathrm{MD}=3.03,95 \% \mathrm{Cl}(-0.64,6.70), P=0.11]$. Considering the greater heterogeneity, the included studies were divided into 1 month of $\mathrm{Hb}$ group, 3 months of $\mathrm{Hb}$ group, and 6 months of $\mathrm{Hb}$ group according to the time of data collection. The results showed that the combined effects were not statistically significant [1 month: $\mathrm{MD}=8.57,95 \% \mathrm{Cl}(-12.07,29.22), P=0.42$; 3 months: $\mathrm{MD}=2.69,95 \% \mathrm{Cl}(-3.12,8.51), P=0.36$; $\mathrm{MD}=2.01,95 \% \mathrm{Cl}(-2.03,6.05), P=0.33]$, namely, empowerment education intervention has no significant effect on improving $\mathrm{Hb}$ in hemodialysis patients (see Figure 6).

\subsubsection{Effect of empowerment education intervention on $\mathrm{Alb}$}

Four studies ${ }^{9,11,14,15}$ evaluated the effects of empowerment education on Alb in hemodialysis patients. The combined results showed that there was no statistical heterogeneity among the included studies $(P=0.009$, $R^{2}=60 \%$ ), so a random effect model was used for metaanalysis. The results showed that there was a statistically significant difference between the empowerment education group and the control group [MD $=2.93,95 \% \mathrm{Cl}$ (2.00, 3.86), $P<0.01]$. Considering the heterogeneity among the studies, a subgroup analysis was performed according to the data collection time. The results showed that there was no heterogeneity between the subgroups ( 3 months Alb: $P=0.21, R^{2}=33 \%$; 6 months Alb: $P=0.15, P^{2}=44 \%$ ); in addition, difference of each subgroup between the intervention group and the control group was statistically significant [3 months: $\mathrm{MD}=2.86$, $95 \% \mathrm{Cl}(1.99,3.74), P<0.01 ; 6$ months: $\mathrm{MD}=3.70$, $95 \% \mathrm{Cl}(2.81,4.59), P<0.01]$, that is empowerment education intervention can improve Alb index in hemodialysis patients. Since only one study was reported in the 6-week Alb subgroup, no subgroup analysis was performed (see Figure 7).

\subsubsection{Effect of empowerment education intervention on serum creatinine}

Three studies ${ }^{9,14,15}$ reported the impact of empowerment education intervention on serum creatinine in hemodialysis patients. The combined results showed that there was statistical heterogeneity among the included studies $\left(P<0.1, P^{2}=74 \%\right)$, so a random effect model was used for meta-analysis. The results showed that there

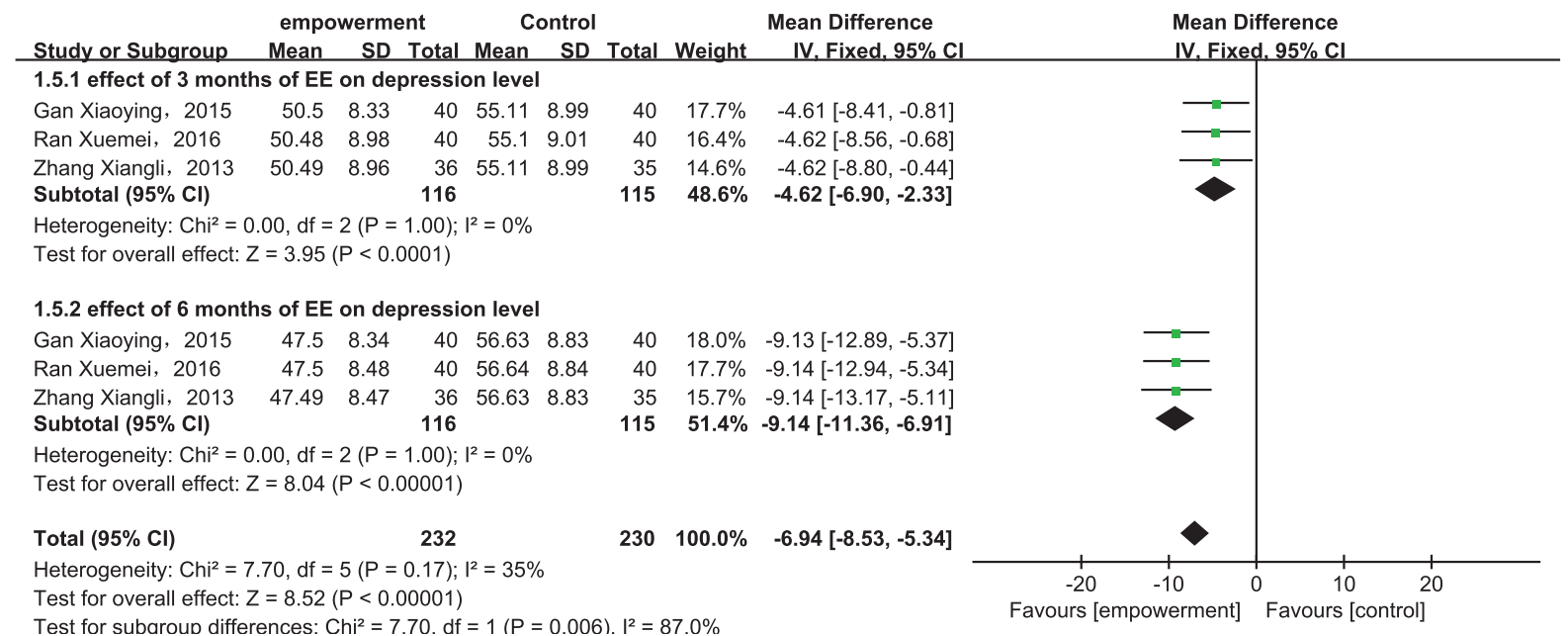

Figure 5. Comparison of depression levels between empowerment education intervention group and traditional education group. 


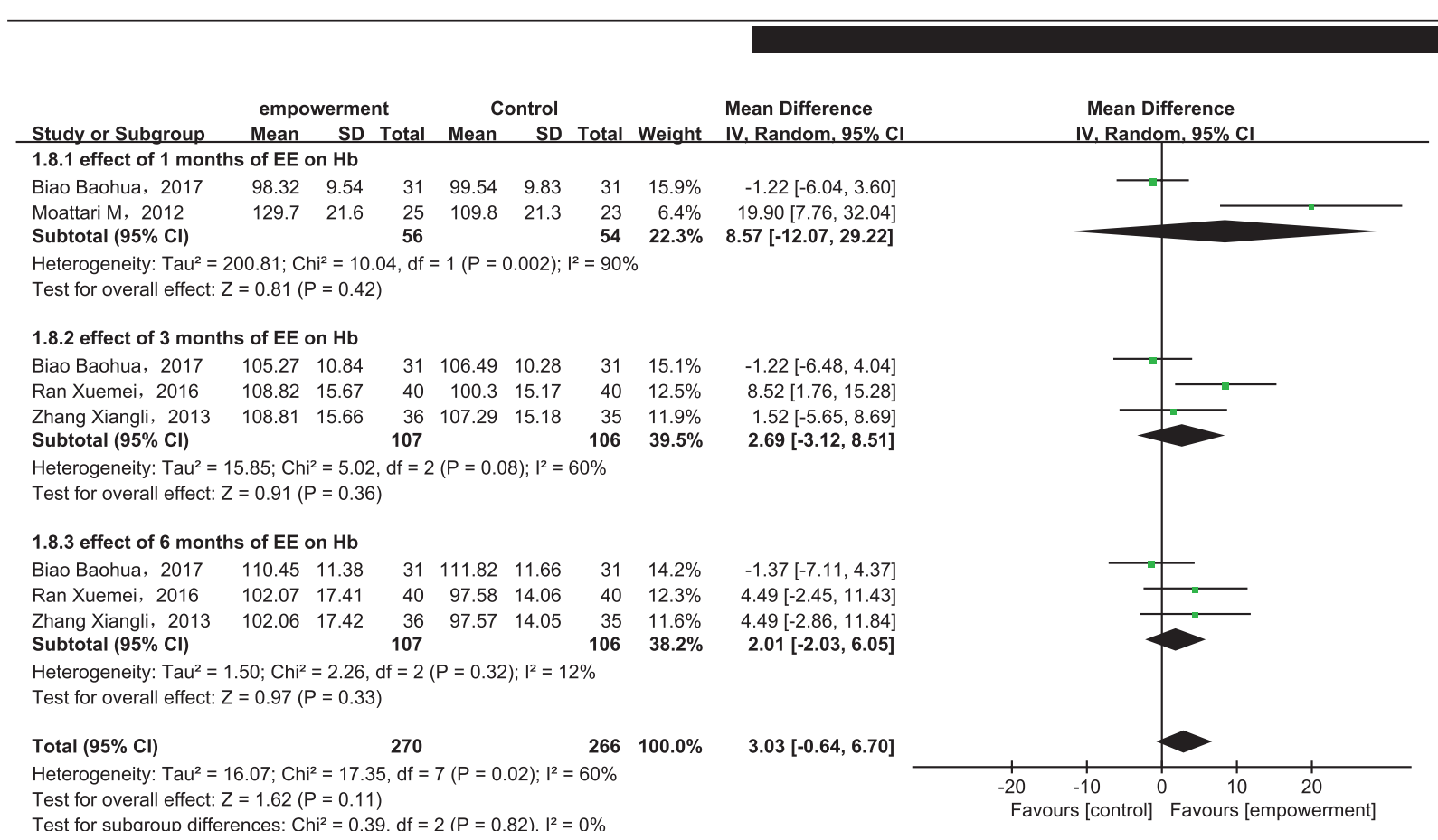

Figure 6. Comparison of hemoglobin between empowerment education intervention group and traditional education group.

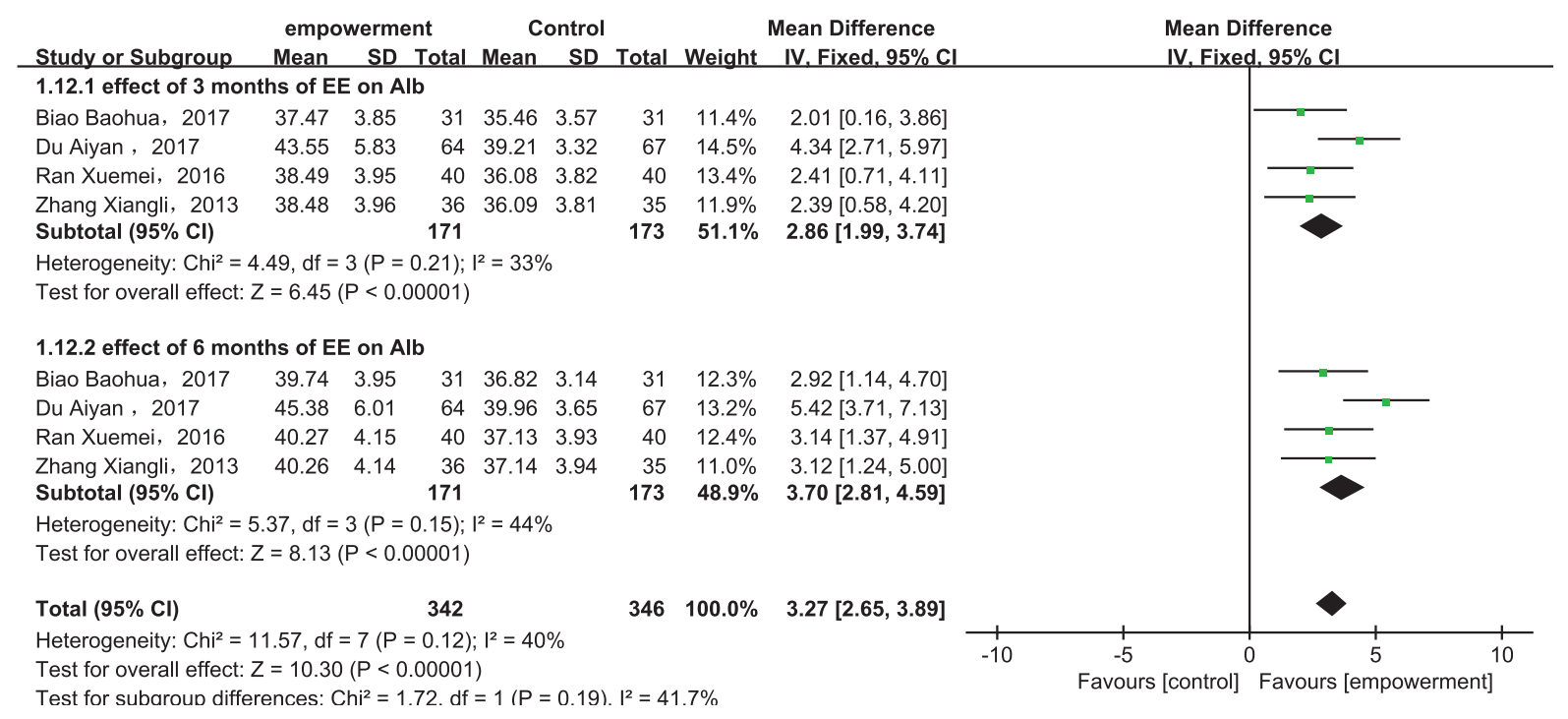

Figure 7. Comparison of albumin between empowerment education intervention group and traditional education group.

was a statistically significant difference between the empowerment educational intervention group and the control group [MD $=-116.46,95 \% \mathrm{Cl}(-171.90,-61.03)$, $P<0.01]$. Taking into account the heterogeneity between studies, the included studies were subgrouped according to the time of data collection. The results showed that there was a statistically significant difference between the empowerment education intervention group and the control group among the subgroups [3 months: $\mathrm{MD}=-84.84,95 \% \mathrm{Cl}(-143.89,-25.79)$,
$P<0.01 ; 6$ months: $\mathrm{MD}=-144.97,95 \% \mathrm{Cl}(-258.72$, $-31.21), P<0.01$ ], that is, empowerment education intervention can improve the serum creatinine index in hemodialysis patients (see Figure 8).

\subsubsection{Effect of empowerment education intervention on BUN}

Two studies ${ }^{15-16}$ evaluated the impact of empowerment education intervention on BUN indexes in hemodialysis 


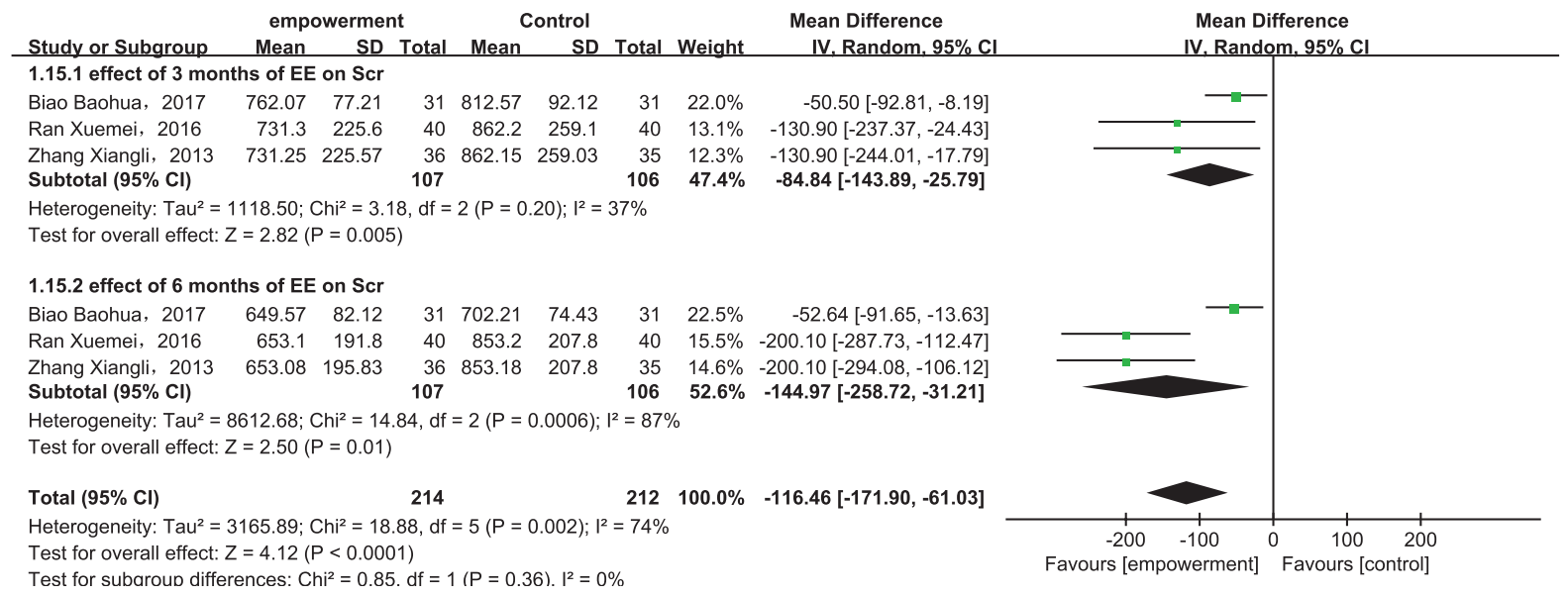

Figure 8. Comparison of serum creatinine between empowerment education intervention group and traditional education group.

patients. The combined results showed that there was no statistical heterogeneity between studies $(P=0.35$, $P^{2}=0 \%$ ), so a fixed-effects model was used to perform a meta-analysis. The results showed that empowerment education intervention can improve the urea nitrogen index in hemodialysis patients [MD $=-0.95,95 \% \mathrm{Cl}$ $(-1.89,-0.01), P=0.05]$.

\subsubsection{Effect of empowerment education intervention on empowerment level}

Two studies ${ }^{17,18}$ evaluated the impact of empowerment education intervention on the empowerment of hemodialysis patients. The combined results showed statistical heterogeneity among studies $\left(P=0.31, P^{2}=3 \%\right)$, so a fixed-effects model was used. The analysis results show that the level of empowerment level between the empowerment education group and the traditional education group has statistical significance, namely, empowerment education intervention can improve the empowerment level of hemodialysis patients [MD $=5.76,95 \% \mathrm{Cl}$ (4.18, 7.34), $P<0.01]$.

\section{Discussion}

\subsection{Methodological quality}

A total of 10 studies were included in this study. One study had a quality rating of $A$. The rest had a quality rating of $B$. The overall quality was moderate and may be related to the stringency of the randomized interventions included in the literature. The included studies used a randomization method, but most studies did not describe the specific randomization method, and the included studies did not specifically describe the allocation concealment and blinding methods, so there may be a certain offset, and therefore, we should pay attention to the concealment and endgame blindness when we make some related researches.

\subsection{Effect of empowerment education intervention in hemodialysis patients}

Empowerment education is an education model in which patients are the whole body and they can participate in decision-making. In fact, educators and patients become friends and cooperate with each other to formulate nursing plans together. ${ }^{19}$ Its intervention is mainly carried out through five steps, ${ }^{20}$ namely, clarifying problems, expressing emotions, setting goals, setting plans, and evaluating results. Each step is crucial. In addition, attention should be paid to clarifying the issues and expressing emotions, always insisting on people centeredness, and paying attention to the patient's own wishes, emotions, and needs. ${ }^{21}$ In this study, metaanalysis was used to evaluate the impact of empowerment education intervention on hemodialysis patients' self-efficacy, depression, and serum, creatinine, Alb, and other biochemical indicators. The results showed that empowerment education can improve self-efficacy, relieve depression, and improve related indicators. The reason may be that hemodialysis patients can vent their bad feelings, face their own health problems correctly, and make correct choices and positive changes.

In assessing the role of empowerment education interventions in the self-efficacy of hemodialysis patients, subgroup analyses were performed considering the heterogeneity. In the 6-week intervention selfefficacy subgroup, self-efficacy was evaluated using the self-efficacy (SUPPH) scale and the remaining subgroups were all managed using the Chronic Disease Management Self-Efficacy Scale. In addition, the 
study ${ }^{10}$ on empowerment education interventions for depression indicators in hemodialysis patients, using the Hospital Anxiety and Depression Scale. Blood biochemical indicators are important indicators for evaluating the nutritional status of hemodialysis patients. Attention should be paid to the conversion of each unit when data are extracted, and data analysis can only be performed when the units are consistent. In this study, serum creatinine, $\mathrm{Alb}, \mathrm{Hb}, \mathrm{BUN}$, and other biochemical indicators are commonly used in domestic units, which are $\mu \mathrm{mol} / \mathrm{L}, \mathrm{g} / \mathrm{L}, \mathrm{g} / \mathrm{L}$, and $\mathrm{mmol} / \mathrm{L}$, respectively. The meta-analysis showed that empowerment education had a certain improvement on serum creatinine, urea nitrogen, and Alb, probably because empowerment education was based on the individualized implementation plan of the patients. The patients' own problems were clearer. However, there was no statistically significant difference in $\mathrm{Hb}$ between the empowerment education group and the control group. The analysis of the causes may be related to the treatment with erythropoietin, and it also may be different investigator or intervention program.

\section{Conclusions}

This study shows that empowerment education intervention can improve the self-efficacy, relieve the depressed mood, and improve the laboratory indicators such as serum creatinine, Alb, and urea nitrogen in hemodialysis patients, but there is no obvious improvement in the $\mathrm{Hb}$

\section{References}

1. Ho YW, Chau KF, Choy BY, et al. Hong Kong Renal Registry Report 2010. Hong Kong J Nephrol. 2010;12:81-98.

2. Amro A, Waldum B, von der Lippe N, et al. Symptom clusters predict mortality among dialysis patients in Norway: a prospective observational cohort study. J Pain Symptom Manage. 2015;49:27-35.

3. Weisbord SD, Mor MK, Sevick MA, et al. Associations of depressive symptoms and pain with dialysis adherence, health resource utilization, and mortality in patients receiving chronic hemodialysis. Clin J Am Soc Nephrol. 2014;9:1594-1602.

4. Rahimi A, Ahmadi F, Gholyaf M. The effects of continuous care Model on depression, anxiety, and stress in patients on hemodialysis. Nephrol Nurs J. 2008;35:39-43.

5. Funnell MM, Anderson RM. The problem with compliance in diabetes. JAMA. 2000;284:1709.

6. Cooper H, Booth K, Gill G. A trial of empowermentbased education in type 2 diabetes - Global rather index. In addition, the contents of empowerment education intervention and the intervention time for hemodialysis patients have not yet been concluded. Therefore, more large-scale, high-quality studies are needed to further evaluate the effects of empowerment education intervention on the self-efficacy, depression, and laboratory indicators of hemodialysis patients.

\section{Limitations}

This study only searched publicly published Chinese and English literature. The lack of systematic search of literature in less frequently used languages may cause a certain bias in the results. Some indicators have heterogeneity due to different assessment tools and cannot extract data for meta-analysis; thus, these limited the scale of meta-analysis. In addition, the random sequence generation and allocation concealment of multiple studies have not been specifically described and may have a certain impact on the reliability of the results.

\section{Ethics approval}

Not declared.

\section{Conflict of interest}

The authors declare that they have no conflicts of interest. than glycaemic benefits. Diabetes Res Clin Pract. 2008;82:165-171.

7. McCarley P. Patient empowerment and motivational interviewing: Engaging patients to selfmanage their own care. Nephrol Nurs J. 2009;36: 409-413.

8. Christian M, Anja M, Christine D, et a1. Clinical research for patient empowerment a qualitative approach on the improvement of heart health promotion in chronic illness. Med Sci Monit. 2008;14:358-365.

9. Zhang X. The Application of Empowerment Theory on Health Education for Hemodialysis Patients. Nanjing: Southeast University; 2013 (in Chinese).

10. Zhao Y. Effect of empowerment theory on knowledge and self-efficacy of 63 hemodialysis patients. $J$ Med Sci Yanbian Univ. 2016;3:218-219 (in Chinese).

11. Du A, Zhou W, Fan J, et al. Effect of dietary management based on empowerment education in 
patients with maintenance hemodialysis. J Nurs (China). 2017;8:65-68 (in Chinese).

12. Gan X, Yin H, Chen $X$. The application of empowerment education in health education of patients with maintenance hemodialysis. Jiangxi Med J. 2015;11:1245-1248 (in Chinese).

13. Qiao J. Effects of Empowerment-Based Education on Fluid-Intake of Hemodialysis Patients. Zhengzhou: Zhengzhou University; 2014 (in Chinese).

14. Ran X. Impact of empowerment education on maintenance hemodialysis patients. Med $J$ Qilu. 2016;1:87-90 (in Chinese).

15. Bian B, Hu D, Shang Q. Effect of empowerment education on nutritional status of elderly maintenance hemodialysis patients. Jilin Med J. 2017;10: 1964-1966 (in Chinese).

16. Moattari M, Ebrahimi M, Sharifi N, Rouzbeh J. The effect of empowerment on the self-efficacy, quality of life and clinical and laboratory indicators of patients treated with hemodialysis: a randomized controlled trial. Health Qual Life Outcomes, 2012;10:115.

17. Royani Z, Rayyani M, Behnampour N, Arab M, Goleij J. The effect of empowerment program on empowerment level and self-care self-efficacy of patients on hemodialysis treatment. Iran $\mathrm{J}$ Nurs Midwifery Res. 2013;18:84-87.

18. Tsay S, Healstead M. Self-care self-efficacy, depression, and quality of life among patients receiving hemodialysis in Taiwan. Int $J$ Nurs Stud. 2002;39:245-251.

19. Li L. Patients are authorized to participate in nursing decision. Foreign Med Nurs Sect. 2003;22: 19-20 (in Chinese).

20. Anderson B, Funnell MM. The art of empowerment. Am Diabetes Assoc. 2005:3-286.

21. Tang TS, Gillard ML, Funnell MM, et al. Developing a new generation of ongoing diabetes selfmanagement support interventions: a preliminary report. Diabetes Educ. 2005;31:91-97. 